E3S Web of Conferences 1, 15005 (2013)

DOI: $10.1051 / \mathrm{e} 3$ sconf/20130115005

(c) Owned by the authors, published by EDP Sciences, 2013

\title{
Heavy metal content and yielding of Italian ryegrass cultivated in the soil intensively fertilized with municipal sewage sludges
}

\author{
J. Wieczorek ${ }^{1}$, F. Gambuś ${ }^{2}$ and A. Baran ${ }^{3}$ \\ ${ }^{1}$ Department of Agricultural and Environmental Chemistry, Agricultural University of Krakow, al. A. Mickiewicza 21, \\ 31-120 Kraków, e-mail: rrwieczo@cyf-kr.edu.pl \\ ${ }^{2}$ Department of Agricultural and Environmental Chemistry, Agricultural University of Krakow, al. A. Mickiewicza 21, \\ 31-120 Kraków, e-mail: rrgambus@cyf-kr.edu.pl \\ ${ }^{3}$ Department of Agricultural and Environmental Chemistry, Agricultural University of Krakow, al. A. Mickiewicza 21, \\ 31-120 Kraków, e-mail: baranaga1@wp.pl
}

\begin{abstract}
The paper contains results of yielding and heavy metal content in Italian ryegrass cultivated in the fourth year of investigations conducted to determine the effect of two sewage sludges and manure applied once (in the first year of the experiment) and four times in the $1^{\text {st }}$ to $4^{\text {th }}$ year of the experiment. A experimental design comprised 8 treatments in 4 replications. Treatment 1 was the control (without fertilization), whereas on treatment 2 exclusively mineral fertilizers were applied. In the first year of the experiment organic fertilization (two different sewage sludges and farmyard manure) were applied on treatments 3-8, whereas in the second, third and fourth year only on variants 6-8. It was done so to make possible checking the residual effect and the effect of cumulated doses of applied organic materials in the subsequent years. Over the next three years of the experiment, the soil in variants 3-5, which was not enriched with organic materials, received mineral fertilization. On the basis of obtained results it was found that four-year sewage sludges and manure fertilization positively affected the amount and quality of Italian ryegrass yield. Total yields obtained on treatments fertilized with organic materials were statistically significantly higher (by about 20\%) than the yields obtained on the treatments receiving mineral fertilizers, and twice bigger as compared with the yield from the control variant. Heavy metals contents in tops of Italian ryegrass on treatments with mineral fertilizers (2-5) was significantly higher as compared with the variants receiving organic materials. In the case of cadmium difference reached up to $100 \%$. Contents of the analyzed heavy metals in Italian ryegrass samples, except cadmium, did not exceed values critical for plants destined for animal feed.
\end{abstract}

Key words: heavy metals, sewage sludges, farmyard manure, Italian ryegrass

\section{Introduction}

The recent years, saw among others an intensive extension of sewer infrastructure in Poland. It is connected with the necessity to make up for neglect in this sphere left by the previous economic system but also with the necessity to meet the obligations resulting from Poland's accession to the European Union in 2004. Both development of sewerage system and the technology of sewage treatment cause that the increasingly more localities in Poland begin to face a problem of management of municipal sewage sludges forming as a by-product. In 2010 municipal sewage treatment plants served about $65 \%$ of the total number of inhabitants of Poland, of which $89 \%$ were city dwellers and $29 \%$ rural inhabitants generating 526.7 thousand $\mathrm{Mg}$ sludge dry mass, of which c.a. $37 \%$ found environmental applications (CSO, 2011). It has been estimated that in
2018 annual production of municipal sewage sludge will increase by about $38 \%$ reaching 726 thousand $\mathrm{Mg}$ d.m.. Sewage sludges may be managed in various ways. The most important methods of sludge disposal comprise among others: environmental application, storage on landfills, burning and other ways, e.g. production of construction materials, etc. (Oleszkiewicz 1998). Because of a considerable soil forming and fertilizer value, as well as relatively lower costs, as compared to burning or storage, environmental (including agricultural) use of sludges from municipal treatment plants seems the best economically justified method of their disposal (Urbaniak, 1997; Gorlach and Gambuś, 1998; Oleszkiewicz, 1998). Agricultural use of sewage sludge is widely popular all over the world. As stated by the European Commission in Eurostat Yearbook (2011) in 2007, the use of sewage sludge in agriculture was different in various European countries. In many 
countries it was on the level of $20-25 \%$ of all produced sludge, however in such countries as Cyprus, Ireland or Great Britain, the percentage constituted about $70 \%$.

Sewage sludge usability for application in agriculture is in the first place determined by organic matter and nutrient concentrations, particularly nitrogen and phosphorus. Potassium content in materials of this type is generally low. However, it should be remembered that beside its beneficial properties, sewage sludge may pose a hazard to the environment, especially due to its concentrations of toxic substances (mainly heavy metals) and a sanitary-biological threat (Baran and Turski 1999). Despite numerous investigations on the use of municipal sewage sludges in agriculture, these problems still need further studies. The paper contains results of yielding and heavy metal content in Italian ryegrass cultivated in the fourth year of investigations conducted to determine the effect of two sewage sludges and manure applied once (in the first year of the experiment) and four times in the $1^{\text {st }}$ to $4^{\text {th }}$ year of the experiment.

\section{Materials and Methods}

The experiment was conducted in a vegetation hall in special plastic pots with volume of about $100 \mathrm{dm}^{3}$ filled with acid soil collected from an arable field in three separate layers, with granular size distribution of light loam (0-20 cm layer) and light loamy sand (20-40 cm and 40-60 cm layers). A general experimental design comprised 8 treatments in 4 replications. Treatment 1 was the control (without fertilization), whereas on treatment 2 exclusively mineral fertilizers were applied. In the first year of the experiment organic fertilization (two different sewage sludges obtained from sewage treatment plants in Krzeszowice and Niepołomice serving agglomerations with RLM 2000-15000 and manure) were applied on treatments 3-8, whereas in the second, third and fourth year only on variants $6-8$. It was done so to make possible checking the residual effect and the effect of cumulated doses of applied organic materials in the subsequent years. Over the next three years of the experiment, the soil in variants $3-5$, which was not enriched with organic materials, received mineral fertilization. For all years of the experiment the amount of organic materials used for fertilization corresponded to the dose of c.a. 100t of manure fresh mass per hectare. The doses of sewage sludges and manure were established according to nitrogen amount. In the discussed year of the experiment it was $9.31 \mathrm{gN}$ per pot. Doses of the other macroelements were equalized with mineral fertilizers to the quantity supplied with the organic fertilizer most abundant in specific element. Detailed information about plant fertilization in previous years of the research was given in other papers (Wieczorek and Gambuś 2006, 2008, 2009). The test plant was Italian ryegrass (Lolium multiflorum) sown to the pots following the fertilizers application. The plants were harvested for green forage thrice, after 40 , 118 and 160 days after sowing. The amount of dry mass yield and heavy metal concentrations were determined in the gathered yield. Collected samples were "dry mineralized" and the mineral contents was assessed in ash solutions using ICP-OES method on JY238 Ultrace spectrometer (Jobin-Yvon).

\section{Results and Discussion}

The sewage sludges revealed a higher content of heavy metals in comparison with manure. However, these metal concentrations did not exceed the amounts permissible in Poland, (Ordinance 2010), so they could be used for fertilization purposes.

Fertilizer variants used in the experiment affected the amount of Italian ryegrass yield (Fig.1). The highest total yields were registered on treatment 6 - fertilized with manure, then on treatment 7 - fertilized with sludge from Krzeszowice and on treatment 8 - fertilized with the sludge from Niepołomice. Obtained results corroborate high effectiveness of organic fertilization. Total yields obtained on treatments fertilized with organic materials were statistically significantly higher (by about 20\%) than the yields obtained on the treatments receiving mineral fertilizers, and twice bigger as compared with the yield from the control variant.

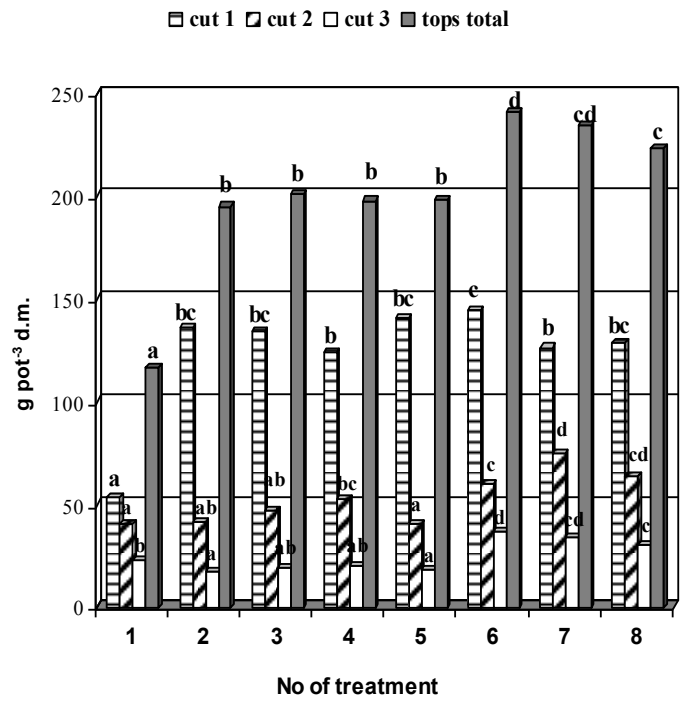

Fig. 1. Field of tops of Italian ryegrass; means marked with the different letters differ significantly $(\mathrm{p} \leq 0.05)$

Analysis of heavy metal concentrations in subsequent Italian ryegrass cuts in most cases revealed the effect of fertilization method on diversification of their content in the yield (Tab.1). The greatest diversification among the treatments was registered for cadmium and nickel. However, for copper no such regularity was observed. Only copper concentrations assessed in the plants from the first cut were over twice bigger than the amounts found in other cuts, irrespective of the fertilizer variant, however in both cases they approximated lower values for this metal assessed in grasses in Poland, which according to Kabata-Pedias (2001) range from 2.2 to 211 $\mathrm{mg} \cdot \mathrm{kg}^{-1}$. Conducted experiment showed that soil 
enrichment in organic matter and introducing additional doses of calcium to the substratum owing to annual application of sewage sludges and manure for the subsequent 4 years, significantly reduced cadmium, nickel, chromium and lead in Italian ryegrass yield. The highest heavy metal contents were assessed on treatments receiving mineral fertilizers in the fourth year of the experiment. Plants from the treatment 2 - fertilized exclusively with mineral fertilizers accumulated the highest doses of $\mathrm{Cd}$ and $\mathrm{Ni}$. Among the eight fertilization variants, the smallest quantities of metals were most frequently determined in the samples from treatment 6 (four times fertilized with manure) and 7 and 8 (annually fertilized with sewage sludges). A single application of organic materials as fertilizers did not have any effect on heavy metal concentrations in cultivated plant shoots in the fourth year after this measure application. Concentrations of investigated heavy metals in Italian ryegrass samples, except cadmium, did not exceed critical content for plants destined for animal feed.

\section{Conclusion}

Four-year organic fertilization definitely affected the crop yield of Italian ryegrass. The greatest increment of green mass was registered for the variants receiving organic fertilization, where manure and sewage sludges were used with supplementary phosphorus-potassium fertilizers. Heavy metal accumulation in Italian ryegrass shoots on treatments where mineral fertilization was used $(2,3,4$, 5) was obviously higher in comparison with plants fertilized with organic materials. Contents of the analyzed heavy metals in Italian ryegrass samples, except cadmium, did not exceed values critical for plants destined for animal feed.

\section{References}

Baran S., Turski R. Selected aspects of the utilization and disposal of waste. AR in Lublin Press, 1999; 137 160.

Central Statistical Office (GUS). Environment 2011. Warsaw 2011.

Table 1. Heavy metal contents in tops of Italian ryegrass $\left(\mathrm{mg} \cdot \mathrm{kg}^{-1} \mathrm{~d} . \mathrm{m}\right.$.)

\begin{tabular}{|c|c|c|c|c|c|c|c|}
\hline \multirow{2}{*}{ Treatment } & \multicolumn{3}{|c|}{$\mathrm{Cd}$} & \multirow{2}{*}{ Treatment } & \multicolumn{3}{|c|}{$\mathrm{Cr}$} \\
\hline & Cut 1 & Cut 2 & Cut 3 & & Cut 1 & Cut 2 & Cut 3 \\
\hline 1 & $* 0.51^{\mathrm{c}}$ & $0.35^{\mathrm{bc}}$ & $0.74^{\mathrm{ab}}$ & 1 & $1.31^{\mathrm{b}}$ & $0.73^{b}$ & $1.32^{\mathrm{bc}}$ \\
\hline 2 & $0.69^{d}$ & $0.41^{\mathrm{cd}}$ & $1.27^{\mathrm{c}}$ & 2 & $0.60^{\mathrm{a}}$ & $0.62^{\mathrm{ab}}$ & $1.20^{\mathrm{abc}}$ \\
\hline 3 & $0.57^{\mathrm{c}}$ & $0.52^{\mathrm{e}}$ & $1.20^{\mathrm{c}}$ & 3 & $1.42^{\mathrm{b}}$ & $0.73^{b}$ & $1.16^{\mathrm{abc}}$ \\
\hline 4 & $0.56^{\mathrm{c}}$ & $0.47^{\mathrm{ed}}$ & $1.00^{\mathrm{bc}}$ & 4 & $0.69^{\mathrm{a}}$ & $0.60^{\mathrm{ab}}$ & $1.50^{\mathrm{c}}$ \\
\hline 5 & $0.56^{\mathrm{c}}$ & $0.55^{\mathrm{e}}$ & $1.23^{\mathrm{c}}$ & 5 & $0.68^{\mathrm{a}}$ & $0.61^{\mathrm{ab}}$ & $1.30^{\mathrm{bc}}$ \\
\hline 6 & $0.20^{\mathrm{a}}$ & $0.19^{a}$ & $0.44^{\mathrm{a}}$ & 6 & $0.65^{\mathrm{a}}$ & $0.61^{\mathrm{ab}}$ & $0.87^{\mathrm{a}}$ \\
\hline 7 & $0.31^{b}$ & $0.23^{\mathrm{a}}$ & $0.69^{\mathrm{a}}$ & 7 & $0.77^{\mathrm{ab}}$ & $0.41^{\mathrm{a}}$ & $0.99^{\mathrm{ab}}$ \\
\hline 8 & $0.30^{\mathrm{ab}}$ & $0.27^{\mathrm{ab}}$ & $0.55^{\mathrm{a}}$ & 8 & $0.62^{\mathrm{a}}$ & $0.49^{\mathrm{ab}}$ & $1.04^{\mathrm{ab}}$ \\
\hline \multirow{2}{*}{ Treatment } & \multicolumn{3}{|c|}{$\mathrm{Cu}$} & \multirow{2}{*}{ Treatment } & \multicolumn{3}{|c|}{$\mathrm{Ni}$} \\
\hline & Cut 1 & Cut 2 & Cut 3 & & Cut 1 & Cut 2 & Cut 3 \\
\hline 1 & $7.99^{b}$ & $2.93^{b c}$ & $2.65^{\mathrm{ab}}$ & 1 & $1.58^{\mathrm{ab}}$ & $1.52^{\mathrm{ab}}$ & $3.50^{\mathrm{bc}}$ \\
\hline 2 & $7.30^{\mathrm{b}}$ & $2.11^{\mathrm{a}}$ & $2.71^{\mathrm{ab}}$ & 2 & $2.72^{\mathrm{c}}$ & $2.28^{\mathrm{d}}$ & $4.45^{\mathrm{c}}$ \\
\hline 3 & $7.90^{\mathrm{b}}$ & $2.82^{b c}$ & $3.08^{\mathrm{b}}$ & 3 & $2.05^{b c}$ & $2.05^{\mathrm{d}}$ & $3.92^{b c}$ \\
\hline 4 & $7.26^{b}$ & $2.66^{\mathrm{bc}}$ & $2.99^{\mathrm{ab}}$ & 4 & $1.53^{\mathrm{ab}}$ & $1.88^{\mathrm{cd}}$ & $2.74^{\mathrm{ab}}$ \\
\hline 5 & $7.19^{b}$ & $2.40^{\mathrm{bc}}$ & $2.49^{\mathrm{ab}}$ & 5 & $2.26^{\mathrm{bc}}$ & $2.40^{\mathrm{d}}$ & $4.00^{\mathrm{bc}}$ \\
\hline 6 & $5.30^{\mathrm{a}}$ & $2.14^{\mathrm{ab}}$ & $2.40^{\mathrm{a}}$ & 6 & $0.85^{\mathrm{a}}$ & $0.91^{\mathrm{a}}$ & $1.93^{\mathrm{a}}$ \\
\hline 7 & $7.50^{\mathrm{b}}$ & $2.50^{\mathrm{bc}}$ & $2.66^{\mathrm{ab}}$ & 7 & $1.46^{\mathrm{ab}}$ & $0.63^{\mathrm{a}}$ & $2.00^{\mathrm{a}}$ \\
\hline 8 & $7.24^{b}$ & $2.98^{c}$ & $2.45^{\mathrm{ab}}$ & 8 & $0.90^{\mathrm{a}}$ & $1.17^{\mathrm{ab}}$ & $1.52^{\mathrm{a}}$ \\
\hline \multirow{2}{*}{ Treatment } & \multicolumn{3}{|c|}{$\mathrm{Pb}$} & \multirow{2}{*}{ Treatment } & \multicolumn{3}{|c|}{$\mathrm{Zn}$} \\
\hline & Cut 1 & Cut 2 & Cut 3 & & Cut 1 & Cut 2 & Cut 3 \\
\hline 1 & $2.90^{b}$ & $5.05^{\mathrm{ab}}$ & $4.85^{\mathrm{ab}}$ & 1 & $53.5^{\mathrm{abc}}$ & $37.7^{\mathrm{abc}}$ & $56.9^{c}$ \\
\hline 2 & $2.17^{\mathrm{a}}$ & $4.67^{\mathrm{ab}}$ & $5.70^{\mathrm{ab}}$ & 2 & $57.3^{b c}$ & $33.1^{\mathrm{ab}}$ & $55.6^{\mathrm{bc}}$ \\
\hline 3 & $2.66^{\mathrm{ab}}$ & $6.26^{\mathrm{b}}$ & $5.87^{\mathrm{b}}$ & 3 & $55.7^{b c}$ & $43.9^{\mathrm{bc}}$ & $49.3^{\mathrm{ab}}$ \\
\hline 4 & $3.07^{\mathrm{b}}$ & $6.42^{\mathrm{b}}$ & $5.82^{\mathrm{b}}$ & 4 & $56.5^{\mathrm{bc}}$ & $39.1^{\mathrm{abc}}$ & $51.5^{\mathrm{abc}}$ \\
\hline 5 & $2.82^{\mathrm{ab}}$ & $5.67^{\mathrm{ab}}$ & $4.82^{\mathrm{ab}}$ & 5 & $57.6^{\mathrm{c}}$ & $40.0^{\mathrm{abc}}$ & $53.1^{\mathrm{abc}}$ \\
\hline 6 & $3.02^{\mathrm{b}}$ & $5.66^{\mathrm{ab}}$ & $4.10^{\mathrm{a}}$ & 6 & $46.6^{\mathrm{a}}$ & $32.5^{\mathrm{a}}$ & $47.7^{\mathrm{a}}$ \\
\hline 7 & $2.27^{\mathrm{a}}$ & $4.22^{\mathrm{a}}$ & $5.13^{\mathrm{ab}}$ & 7 & $48.7^{\mathrm{ab}}$ & $38.2^{\mathrm{abc}}$ & $55.6^{\mathrm{bc}}$ \\
\hline 8 & $2.78^{\mathrm{ab}}$ & $4.98^{\mathrm{ab}}$ & $4.70^{\mathrm{ab}}$ & 8 & $53.3^{\mathrm{abc}}$ & $45.1^{\mathrm{c}}$ & $55.2^{\mathrm{bc}}$ \\
\hline
\end{tabular}

*Means in columns differ significantly $(\mathrm{p} \leq 0,05)$, if they are not marked with the same letter 
European Commission. Europe in figures-Eurostat Yearbook 2011. Luxembourg 2011.

European Commission. Europe in figures-Eurostat Yearbook 2011. Luxembourg 2011.

Gorlach E., Gambuś F. Evaluation of sewage sludges as fertilizer in pot experiment. Acta Agr. et Silv. ser. Agr. 1998; 36:23-35.

Kabata-Pendias A. Trace elements in soil and plants. CRC Press, Londyn 2001.

Oleszkiewicz J. The sewage sludge management. Decision Maker's Guide. LEM Press, Krakow 1998.

Ordinance of the Minister for the Natural Environment of 13 July 2010 on municipal sewage waste. Journal of Law No 134, item 1140.

Urbaniak M. Processing and utilization of sludge from municipal wastewater. Ekoinżynieria, Lublin-Łódź 1997.
Wieczorek J., Gambuś F. Comparison of successive manure and sewage sludge effects on yielding and chemical composition of the white mustard in a lysimeter experiment. Advances of Agricultural Sciences Problem Issues, 2006; 512: 627-635.

Wieczorek J., Gambuś F. The effect of fertilization with farmyard manure and sewage sludges on yields and chemical composition of Italian ryegrass. Ecological Chemistry and Engineering, 2008; 15(10): 11631172.

Wieczorek J., Gambuś F. Comparison of farmyard manure and sewage sludge effects on yielding and chemical composition of the sunflower in a lysimeter experiment. Advances of Agricultural Sciences Problem Issues, 2009; 537: 359-368. 